\title{
THE ROLE OF TOP MANAGEMENT IN ANALYZING THE PROFITABILITY OF A COMPANY
}

\author{
Silvana Pašovska
}

DOI: https://doi.org/10.31410/ITEMA.S.P.2019.141

\begin{abstract}
The reaffirmation of the elements of the market economy system imposes the need to redefine the motives for management and the categories for expressing the efficiency of the business entities. Accordingly, the substance and the manner of expressing and measuring profitability undergo changes characteristic in the standards of the market economy and thus the basic starting point for quantifying profitability is profit. In this way, assumptions are made to understand the purpose of the principle of profitability that should be studied through the following components and relationships:

- Global relationship between the profit and the assets engaged,

- $\quad$ the partial relationship between the elements of the profit and the elements of the assets engaged,

- analysis and quantification of the factors that determine the size, the structure and the dynamics of the profit, i.e. the size and dynamics of the engaged assets on the other hand.
\end{abstract}

Starting from the conclusion that the integral part of the complex of the profitability is the engaged assets, it is necessary to consider not only the volume of the investment and engagement of those assets, but also the intensity of their use and spending. The amount of the average engaged and invested assets is determined by two sizes:

- $\quad$ the amounts of assets engaged and invested in the individual production process cycles, and

- the duration of their engagement.

Keywords: Profitability, Management, Business, Financial Analysis, Portfolio Investment.

\section{INTRODUCTION}

The application of the principle of profitability at the level of individual companies, confirms the purpose and the motive that should be achieved with this principle. In the long term, the profitability is manifested as maximizing of the financial result with minimum capital investment (assets). The expression of profitability based on the relationship between the profit and the capital, i.e. invested assets, emphasizes the need to specify the type of capital that will be the starting point for measuring profitability. In the context of financial analysis, and in function for increasing profitability, the borrowed capital is particularly interesting, which through the amount of financing costs (interest), affects the reduction of the final effects and the realized profitability. It follows from the foregoing that one of the tasks of the financial policy is to reduce the price of the funding sources which will create assumptions for maintaining financial balance and stable financing relationships.

\section{FUTURE RESEARCH DIRECTIONS}

\subsection{Profitability analysis}

Every company, in order to achieve full success in its operations, must take into account the costs incurred in production (cost-effectiveness), the engagement of the workforce in terms of the realized production (productivity), and to perform its tasks with the least amount of engaged

University St. Kliment Ohridski-Bitola, Scientific Tobacco Institute, Prilep, Republic of North Macedonia 
assets. That requirement - the results of the process of operating to be achieved with as little amount of engaged assets as possible - represents the principle of profitability. So, profitability reflects the final business success of any corporation. The principle of profitability by definition requires you to achieve as much profit as possible by engaging less in reproduction. Profitability as a partial expression of the quality of the economy and expresses the efficiency of the assets engaged in generating profits. The formula for expressing profitability is:

$$
P=\frac{\text { Profit }}{\text { Engaged assets }}=\frac{P}{A}
$$

Profitability, in terms of profit, depends on the amount of the total income earned, then on the size of the material cost of reproduction, the engaged assets and on the cycle of reproduction itself. The size of the total income affects the profitability if the company makes full use of its capacity and sells its production at selling prices that will enable it to profit and vice versa, with reduced capacity utilization it reduces the total income and thus the profit, which in turn has less profitability. The total income is also dependent on the selling price, so if lower sales price is achieved the total income is reduced, i.e. the profitability is reduced.

Since profitability is the relationship between the profits made on the one hand and the assets engaged on the other, the problem of its measuring will depend on the exact expression of their magnitudes. It is, above all, an indicator of business success. Hence companies are required to dispose of a method by which they can provide accurate data on the success achieved, that is, they will be able to have an accurate picture of the dimensions of the results achieved. The efforts for productive and economical operation have appropriate effects on the profitability of the operation. Measures taken to increase productivity and economy directly affect the profit, its size directly impacts the degree of profitability. Profitability indicators can be grouped as partial and global, i.e. synthetic. The first relate to the rate of business and net profit whose analysis and determination is based solely on periodic income statements. The second indicators cover the rate of return on the total own assets, which inevitably assumes that for their determination and analysis it is necessary to use the income statement and the balance sheet. The income statement should be structured in such a way as to enable analysis of the interdependence of the incomes, expenses, inter-phase and final results of the company's operations for the specific time period. That analysis can have two different aspects. One deals with examining the relative share of certain segments of the expenditure and the results of the realized sales income. This analysis is usually referred to as a ratio analysis of the income statement. The second aspect concerns the dynamic combination of the invoices on which the difference between the income and expenditure, business and net profit depends. This analysis has taken place with the breakpoint methodology or profitability graph, which can be presented as follows in Figure 1.

The first information in Figure 1 relates to the intersection point of the line of the total income and the total costs, in which the business profit is equal to zero. In this case, the company only reaches the lower limit of profitability, whereby the volume of realization can be calculated by the following formula:

$$
\text { Lower profitability limit }=1-\frac{\frac{\text { Fixed costs }}{\text { Variable costs }}}{\text { Income from sale }}
$$




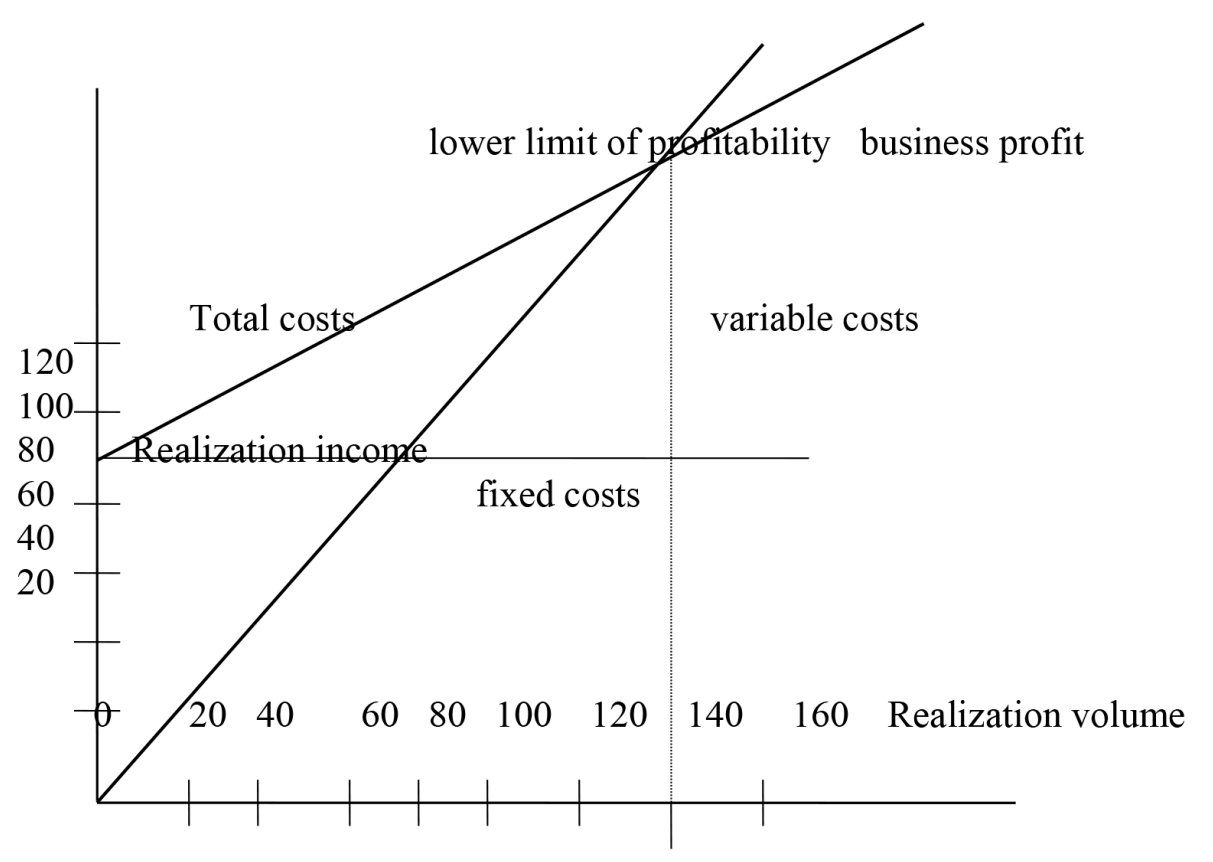

Figure 1. Profitability graph

Source: own analysis

The combination of factors, which provides only a complement to the regular costs, is a minimum requirement for existence, which means that with determining the lower limit of profitability, the analytical sense of the profitability graph does not exhaust. On the contrary, its task is to strive to achieve the optimal combination of the relevant factors in order to maximize the business profits. The purpose may be the basis for structuring the income statement, i.e. for determining the order of reimbursement of expenses with recurring income from the realization. Such a structure of the income statement, in particular, exists in the variable cost calculation system (Direct Costing), in which the variable costs are proportionally complemented by the realization of the products and the services, while the fixed costs fall entirely on the current income.

The most general financial indicator of profitability is the rate of the total business assets which, in financial and accounting terms, is a periodic increase of the total business assets that are used to perform the regular business activities of the corporate enterprise during the same period.

Accordingly, the rate of return on the total business assets can be obtained directly from the following relationship:

$$
\text { Rate of return on total business assets }=\frac{\text { Business profit }}{\text { Average business assets }}
$$

This rate should show how much the average business invested assets earn during the observation period. The relative importance of that growth can only be talked about in the context of time and spatial analysis. The time analysis refers to the comparison of the current rate of return from the previous periods, while the spatial analysis implies comparing of the current rate of return with the returns of other companies in the same production branch, i.e. with the average rate of return of the whole branch. Only in these relationships can be obtained a competent impression of whether and how effectively the analyzed company is using its assets. However, analytically, that expression of the profitability of the business investments that derives from the individual determinants of the rate of return, is more significant. These are the following deter- 
minants: turnover ratio of an average business assets and the business profit rate in terms of the realization income. Their relationship with the rate of return can be explained by the so-called triangular interdependence that includes the net realization income, the average business assets and the business profit. Graphically, this interdependence is as follows:

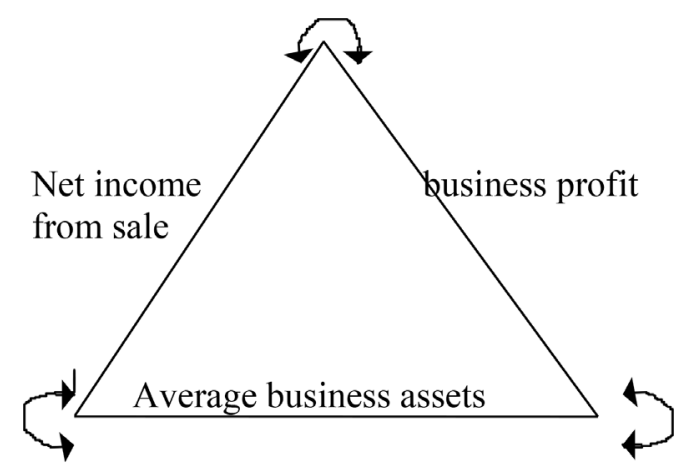

Figure: 2 - Triangular Interdependence

(net income from sale, business profit, average business assets)

Source: own analysis

$$
\begin{aligned}
& \text { Rate of business profit }=\frac{\text { Business profit }}{\text { Net income from sale }} \\
& \text { Turnover ratio of assets }=\frac{\text { Net income from sale }}{\text { Average assets }} \\
& \text { Rate of return of business assets }=\frac{\text { Business profit }}{\text { Average assets }}
\end{aligned}
$$

Converted as a simple equity, this interdependence shows that the rate of return on business assets is the product of the ratio of the average engaged assets and the rate of business income on the realization profit. Namely:

$\frac{\text { Business profit }}{\text { average business assets }}=\frac{\text { net income from sale }}{\text { average assets }} \frac{\text { business profit }}{\mathrm{H} \text { net income from sale }}$

This clearly shows that maximizing the rate of return inevitably implies a constantly acceleration of the turnover of the total business assets, as well as an increase in the rate of profit on the realized income. In this context, the analysis should show that with smaller investment in business assets, should be achieved greater volume and income from the sale, with lower cost of operating (maximizing the profit rate), since only in this way can affects the constant increase in the return on business assets as the most general financial indicator of profitability. Unlike the business profit which is the effect of the operation of the total assets, the net profit shows the effect of the investment of own assets. Raising the own capital is a particularly important purpose of the operation and it can be concluded that the relative relationship between the net profit and the own sources of financing is an important qualitative indicator in the financial analysis.

This relative ratio is called the rate of return on the own assets, which is determined as follows:

$$
\text { Rate of return on own assets }=\frac{\text { net profit }}{\text { average own assets }}
$$

The rate of return on own assets and the rate of return on the total business assets can be explained by the triangular interdependence, which is represented by the following scheme: 


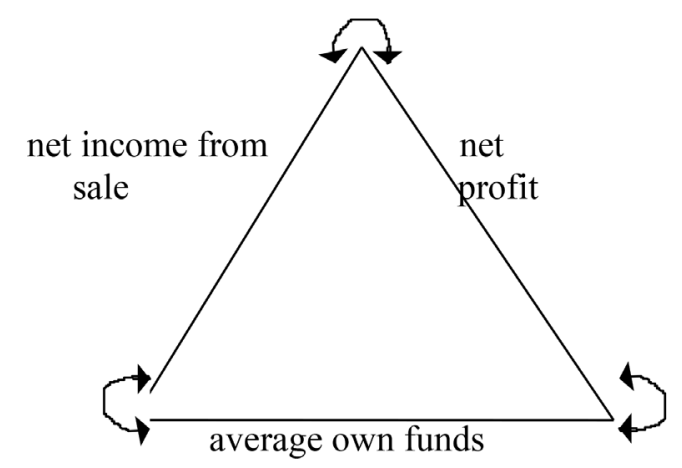

Figure 3. Triangular Interdependence

(rate of return on own funds and rate of return on total business assets)

Source: own analysis

$$
\begin{aligned}
& \text { Rate of net profit }=\frac{\text { net profit }}{\text { net income from sale }} \\
& \text { Own assets turnover ratio }=\frac{\text { net income from sale }}{\text { average own funds }} \\
& \text { Rate of return on own assets }=\frac{\text { net profit }}{\text { average own funds }}
\end{aligned}
$$

This interdependence gives rise to equality in which the rate of return on own assets appears as a product between the turnover ratio on own assets and the rate of the net profit on the realization incomes. In other words, that is the following relationship:

$$
\frac{\text { Net profit }}{\text { average own funds }}=\frac{\text { net income from sale }}{\text { average own funds }} \frac{\text { net profit }}{\text { H net income from sale }}
$$

Based on the foregoing, it can be concluded that all factors affecting the rate of return on total assets directly and simultaneously reflect the rate of return on own funds. Namely, this rate is part of the total assets, and the growth of the own funds in the process of production and realization cannot be done at a rate greater than the rate of return on the total assets.

However, practice shows that this can be in some cases, where the reasons should not be sought in the action of the factors that regulate the regular activity of the corporate enterprise. The reasons should be sought in certain stand-alone effects of the financing from borrowed sources and the profitability of the own capital, i.e. in the intensity of the financial leverage effect. Perceiving and emphasizing the qualitative differences between the basic economic principles or what are still called objective economic principles and the principles of organizational methods for achieving the objective does not only arise from the intention to systematize the scientific approach, but the purpose of a studio treatment involves not only the formulation of the economic principles, but also a development of methods that will analyze and control the extent of realization of goals of each principle separately and in a specific situation. In this way it is possible to establish relationships and relationships between the achieved results and the investments in the reproduction process. Namely, the principles of liquidity and security should enable the achievement of the objectives of the basic economic principles. This means that in market-oriented economies, the quality of the economy is not only determined by the general economic laws, but also by the type and intensity of the influence of numerous direct and indirect factors. The problems related to the quality of the economy expressed through the principle of profitability can be allocated to the changes of the two aggregate economic contents:

- profit, and

- engaged assets. 
Determined by the impact of the social, technical and organizational factors, the quality of the achieved profitability varies depending on whether the factors cause changes in the amount of profit made or on the value of the assets invested. Therefore, an additional problem in studying the complexity of profitability is not only the identification of the factors, but also the differentiation of the dynamics of the realized profitability resulting from the action of those factors. Differentiating the impact of the factors that cause changes in the complexity of the profitability, in its analysis, creates additional methodological problems. Namely, the changes that have an impact on the quality of the economy and the reasons that cause these changes must be permanently discovered and quantified in order to enable the qualitative implementation of the objectives of the profitability principle.

In this context, through a practical example we will measure the profitability of operating of one company using hypothetical indicators. For this purpose, we will calculate the rate and the business result (profit), the rate of the net profit, the rate of return on total assets and the rate of return on the own funds. We assume that the business profit in one company is 98,928 denars, and the net profit is 6,313 denars.

The financing of the company comes from foreign sources, which causes high financial expenses, which amount to 175.709 denars. It speaks of a heavy financial burden on the company, i.e. a high factor of financial leverage. This has a negative impact on the overall performance of the business, which can be seen from the following indicators:

$$
\text { Rate of Business Profit }=\frac{\text { Business Profit }}{\text { Total Income }} * 100=\frac{98,928}{1,628,067} * 100=6,075
$$

This means that the company for every income of 100 denars of sales of products and services in the current year, realized an average business profit of 6,076 denars.

$$
\text { Rate of Net Profit } t=\frac{\text { Net Profit }}{\text { Total Income }} * 100=\frac{6,313}{1,628,067} * 100=0,38
$$

This means that for every income of 100 denars from the sale of products and services, the company realized 0.38 denars net profit.

$$
\text { Rate of return on total engaged assets }=\frac{\text { Business Profit }}{\text { Average engaged assets }} * 100=\frac{98.928}{1.957 .115} * 100=5,05
$$

The rate of 5.05 denars indicates that for every 100 denars average invested funds, the company has increased those funds by 5.05 denars.

$$
\text { Rate of return of own business assets }=\frac{\text { Net Profit }}{\text { Average Own Assets }} * 100=\frac{6.313}{1.314 .735} * 100=0,48
$$

It shows that for every 100 denars of own invested assets, the company has increased those assets by 0,48 denars. From this it can be concluded that the growth of the part of the business assets that is financed from own sources is very low. The very low profitability of the own business assets is due to the very high cost of the foreign sources of financing of the company and due to the negative exchange rate differences. 


\section{CONCLUSION}

Based on all of the foregoing in relation to the financial analysis, we can deduce the following findings:

- In order to provide a valuable assessment of a corporation's financial position, activities and performance, a financial analysis based on standards or criteria for the relevant assessment of the corporation's financial and business activities is required.

- The main point of the financial analysis is to examine and discover the corporation's internal reserves. This will be achieved by a permanent analysis of short deadlines, thorough, detailed, comprehensive analysis of the total financial flows, which will provide selective, concise and functional information.

- Successful financial analysis must start from the set and results of the financial policy, because they are a complex and inseparable whole, whose complexity comes from the whole process of reproduction in all its stages

- Careful assessment of the liquidity, solvency, activity, indebtedness and profitability of the companies, with a proper assessment of the current market trends and the state of stock supply and demand, should significantly contribute to the achievement of the basic goals of the portfolio investment - capital gains income and dividends as return on the invested capital.

\section{REFERENCES}

Afuah, A (2003) Innovation Management Strategies, Implementation and Profits, Oxford University Bownder, B. I dr. (2010), Innovation strategies for creating competitive advantage, Research Technology Management

Daniels, J., Radebaugh, L., \& Sullivan, D. (2002). Globalization and Business. New Jersey: Prentice Hall

Wallerstein, I. (2000). Globalization or the age of transition? International Sociology,

Hil Č., (2010) Meǵunaroden biznis, natprevaruvanje na konkurentniot pazar, prevod na Vladata na R.M.,

Lee, J.\& Gang, Y. (2010). Main characteristics of technological entrepreneurship and the impact of governmental policies in Korea, International Journal of Entrepreneurship and Innovation Management

Madrid-Guijaro, A., Garcia, D., \& Van Auken, H. (2009) Barriers to Innovation among Spanish Manufacturing SMEs, Journal of Small Business Management

Littunen, Hannu; Niittykangas (2010): The rapid growth of young firms during various stages of entrepreneurship. Journal of Small Business and Enterprise Development.

Autio, Erkko; Kronlund, Mathias; Kovalainen, Anne (2007): High-Growth SME support initiatives in nine countries: analysis, categorisation, and recommendations. Report prepared for the Finnish Ministry of Trade and Industry. MTI Publications

OECD, Organisation for Economic Cooperation and Development Measuring Entrepreneurship. The OECD-Eurostat Entrepreneurship Indicators Programme. By Mariarosa Lunati, Jeroen Meyer zu Schlochtern and Gueram Sargsyan. OECD Statistics Brief, November 2010

Reinstaller A. (coord.), Hölzl, W., Janger J., Stadler, I., Unterlass F., Daimer S., Stehnken (2010): Barriers to internationalisation and growth of EU's innovative companies. PRO INNO Europe: INNO-Grips II report. Brussels: European Commission, DG Enterprise and Industry. http://www.proinnoeurope. eu/sites/default/files/newsroom/2010/12/InnoGripsII_Report_Barriers.to_.internationalisation.and_.growth

Deardorff's Ğlossary of International Economics, "policy”, accessed 2 May 2010.

Strategija za ekonomski rast preku razvoj na mali i sredni pretprijatija"- Sojuz na stopanski komori na Makedonija, January 2012. 